\title{
RESILIENCE AND URBAN-TERRITORIAL SYSTEMS. APPROACHES COMPARISON
}

Angela Colucci*

Politécnico de Milán, Italia

Schematic summary from families of literature on Resilience. Figure elaborated by Revista M from author's information.
M. Architect, Ph.D. in planning. Researcher and professor. Adjunct Professor at Politecnico di Milano - Italy (courses of urbanism, and urban design). Since 2008 she is a member of the Resilience and Risks mitigation strategies thematic group of AESOP (Co-Responsible and Coordinator of the Research action domain). She took part, as research staff or partner, to various research projects on the sustainable risk management and on landscape planning. She is a senior partner of the cooperate company since the 2004 worked a large number of planning and strategic environmental assessment, consulting for local and regional administrations in the planning, environmental and landscape aspects. angela.colucci@polimi.it

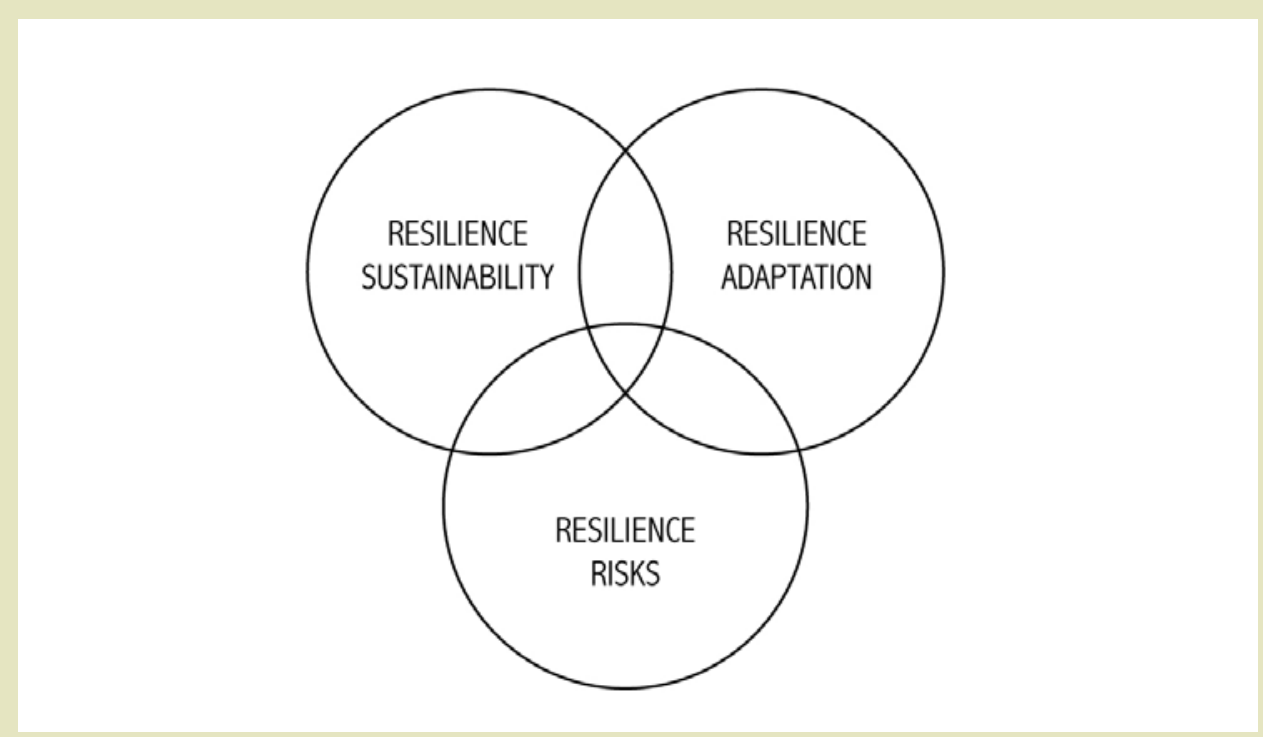

\section{ABSTRACT}

Since the end of the last century, with a significant increase over the last few years, resilience has featured as key concept in many technical, political papers and documents, and appears in many researches. In this paper we present a summary of the literature approaches comparison (initial survey stage of the research) with the aims to identify and understand the approaches to resilience developed; identify which aspects and what resilience strategies these approaches share and propose. The aim is to understand whether the proposed concept of resilience, or rather strategies, constitute progress and contribute to innovation in the areas of urban planning and design in relation to risk mitigation. The first results presented will underline:

- The shared resilience strategies and the common concepts taken form the resilience approach and used for the urban systems strategies management/visions;

- The methodological and planning instruments used for the integration of resilience inside the planning process;

- The innovation aspects developed by the different authors and experiences that could enrich risk mitigation polices.

\section{KEYWORDS}

Resilience, Risks prevention, Risk mitigation, Urban/territorial systems. 
RESILIENCIA Y SISTEMAS URBANO-

\section{TERRITORIALES. COMPARACIÓN DE ENFOQUES}

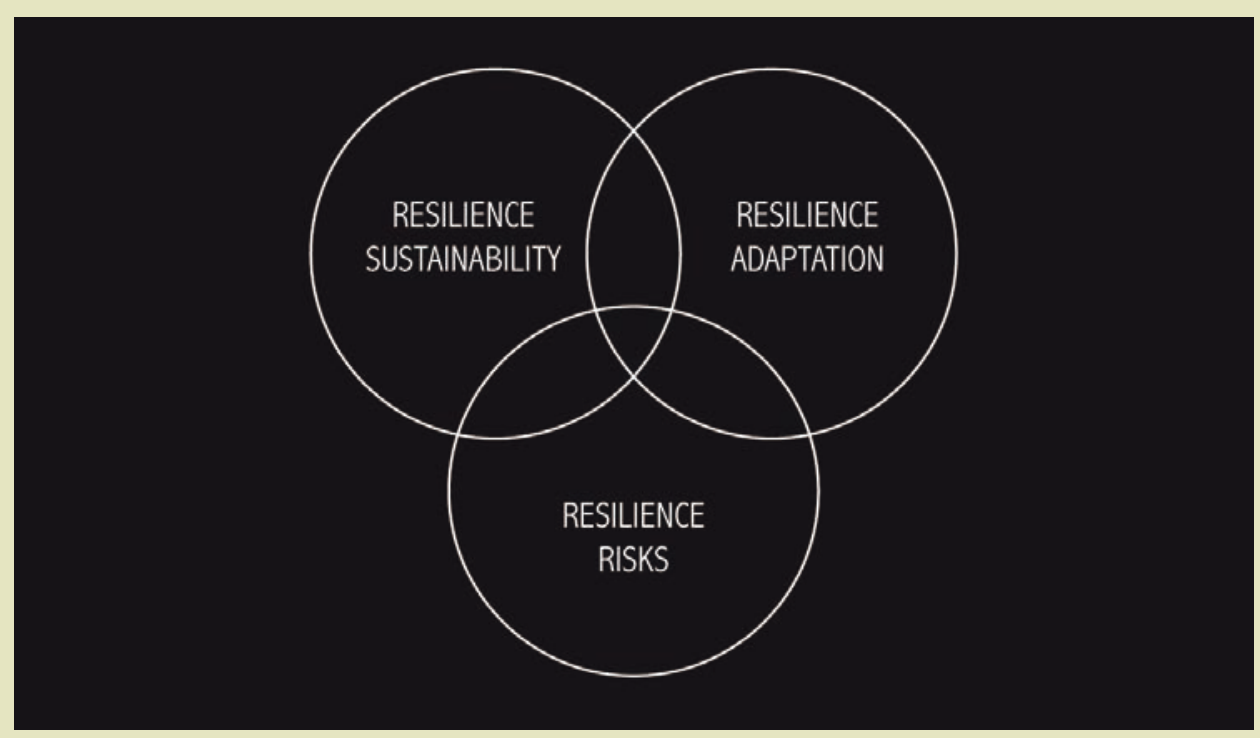

Dibujo esquemático de literatura sobre grupos de Resiliencia. Elaborado por Revista M a partir de información del autor.

\section{RESUMEN}

Desde finales del siglo pasado, con un aumento significativo en los últimos años, se ha caracterizado a la resiliencia, como un concepto clave dentro de documentos políticos y técnicos y aparece en numerosas investigaciones. En este artículo se presenta un resumen de los diferentes enfoques existentes (primera etapa de la investigación) con el objetivo de identificar y comprender los métodos de la resiliencia desarrollada e identificar qué aspectos y que estrategias de resiliencia proponen y aportan estos enfoques. El objetivo es comprender si el concepto propuesto de resiliencia, u otras estrategias, constituyen un avance y contribuyen a la innovación en el ámbito de la planificación urbana y diseño en relación con la mitigación del riesgo. Los primeros resultados presentados destacarán:

- Las estrategias de resiliencia propuestas y los conceptos comunes a los diferentes puntos de vista en relación con la capacidad de resiliencia utilizados dentro de estrategias / visiones de gestión en los sistemas urbanos.

- Las herramientas de programación y metodología utilizadas para la integración de la resiliencia en procesos de planificación.

- Los aspectos de innovación desarrollados por diferentes autores y experiencias que puedan enriquecer las políticas para mitigar el riesgo.

\section{PALABRAS CLAVE}

Resiliencia, Prevención de riesgos, Mitigación de riesgos, Sistemas urbanos/territoriales. 


\section{ADOPTING RESILIENCE'}

The concept of resilience, and the term itself, is used in many disciplines (from engineering to the natural sciences, psychology and sociology) with meanings that are not always the same.

In the discipline of ecology, from which the agreed term used here is taken (and which, in a nutshell, epitomises the capacity of a system to adapt itself in response to the action of a force, achieving a state of equilibrium different from the one it originally had), resilience has been defined and explained in different way, and has evolved in line with the innovations that have occurred in that discipline (White, 20II).

Generally speaking, we have seen this concept become widespread in recent years, often used as a key concept in many documents and books, at conferences and on websites. More recently, resilience has been used also when shaping development strategies for cities, and defining alternative development models for urban systems, local communities or social-ecological systems on a considerably bigger scale.

The concept of ecological resilience, as it relates to the development of territorial systems, was officially introduced into international politics and the European Union in 2005 when the document Resilience and Sustainable Development: Building Adaptive Capacity in a World of Transformations ${ }^{2}$ was first presented.

The on-going research presented here focuses on the concept of resilience with regard to the development of regions, cities and local communities.

While not claiming to be complete, in terms of the widespread disciplinary and political/ social interest, this paper presents a summary of the first stage of the work carried out, and consists in a comparison of the wide-ranging literature published on the concept of resilience and cities (and/or resilience and regional systems).

The research, in relation to which this paper presents a summary of the initial survey stage, has three main aims:

I) Understanding the approaches to resilience developed so far, and identifying which aspects (concepts, strategies and so on) of these approaches are shared (or not shared);

2) Understanding which strategies are being proposed for resilient regions, cities or social-ecological systems (and pointing out the shared strategies);

3) Understanding whether the resilience strategies proposed involve innovations in urban and regional development disciplinary fields.

I A paper published on the Journal TEMA (by Angela Colucci in 20 I2, see bibliography) presents the research and the whole literature approaches, this paper focuses on the Risk approach to resilience and on the main results of the literature comparison.

2 Building Adaptive Capacity in a World of Transformations (Background paper to WSSD) is a technical-scientific paper in support of the Swedish Government's Environmental and Scientific Advisory Council during the World Summit on Sustainable Development 
The research aim is to comprehend whether the concept of resilience, or rather, whether the strategies of resilience proposed constitute progress and contribute to innovation in the areas of urban planning and design.

Three main families of literature have been identified from the recent literature promoting resilience as a key strategy. For each of these families the aim of the research - at this early stage - was to understand which particular concept and which aspects of resilience are used, which resilience strategies are proposed, how the term 'city' is defined and interpreted and, consequently, which are the key concepts related to strategies for resilient cities.

\section{How can resilience be defined?}

The concept of resilience has two main definitions involving different visions and approaches with regard to the concept of stability (Holling and Gunderson, 2002). The most common established definition may be called 'engineering resilience': in physics (and engineering), the resilience of a material is the property that enables it to resume its original shape after being deformed. This definition recalls the concepts of control, consistency and predictability.

The second definition, 'ecosystem resilience' is based on the concepts of persistence, change/unpredictability, adaptability and variability, emphasising conditions that are far from aequilibrium. Resilience is the property of complex systems to react to stress phenomena by activating response and adaptation strategies in order to restore the mechanisms by which they function. Resilient systems under stress react by regenerating themselves while maintaining the functionality and recognisability of the systems. Thus, resilience does not imply the restoration to an initial state, but the restoration of functionality through change and adaptation.

In ecology, resilience derives from functional strengthening through the various levels and hierarchies and from functional overlap between the levels. The vulnerability of the systems gradually increases as the sources of regeneration (diversity, redundancy, functional overlap and so on) and functional diversity are reduced.

This article refers to the concept of ecosystem resilience, and all the papers and documents consulted refer to this agreed notion of resilience.

\section{THE LITERATURE: FAMILIES AND APPROACHES}

Since the end of the last century, and with a significant increase over the last few years, resilience as a key concept has featured in many technical and political papers and documents, and in a great deal of research that has been undertaken. The paper focuses on the texts that combine resilience with strategies, processes and models for the development of cities, communities and regions.

It is possible to identify three main families within the literature (to which can be added best practices, documents of intent and a large number of websites as research platforms, sharing of experience, networks of best practices and so on): 
a) Resilience and territorial risks: resilience is used as a key concept for the innovation of territorial risk mitigation/management strategies (with the integration between the risk mitigation goals and the regional quality goals).

b) Resilience and sustainability: the concept of resilience is used as a way to gain the sustainability of the development of social-ecological systems.

c) Resilience and adaptation: the resilience is used as the key concept to the adaptation strategies with regard to climate change, natural resources reduction and the quality of local communities.

Assigning the contributions of the different authors to one of these three families has inevitably been forced in some cases. As we shall see, many concepts and strategies are common and shared, and, while the family of origin can still be identified, there is often intertwining and overlapping.

A synthesis of main characteristics of the families of "Resilience and sustainability" and "Resilience and adaptation" are below underlined (Table I). This paper focuses on the family of "Resilience and Risk" aspects.

Table I: A synthesis of main characteristics of the families of "Resilience and sustainability" and "Resilience and adaptation". Source: Elaborated by the author.

\begin{tabular}{|c|c|}
\hline $\begin{array}{l}\text { RESILIENCE AND } \\
\text { SUSTAINABILITY }\end{array}$ & $\begin{array}{l}\text { It is possible to relate the first group of authors at The Resilience Alliance }{ }^{3} \text {, a } \\
\text { multidisciplinary network of researchers promoting regional and local develo- } \\
\text { pment processes based on resilience. The family of texts is undoubtedly very } \\
\text { large, and includes such authors as Carl Folke, Lance Gunderson, CS Buzz } \\
\text { Holling, Elinor Ostrom, Johan Colding, Fikret Berkes, and numerous others. } \\
\text { Resilience is used as a key concept to achieve sustainable development. While } \\
\text { accepting the definition of sustainability as a given, the debate on the different } \\
\text { routes (ways) to ensuring sustainable development is certainly more complex. } \\
\text { The approach to complex systems and resilience is part of this debate. } \\
\text { The common distinguishing features of a huge and complex range of authors, } \\
\text { research and experiments, are: } \\
\text { a sizeable theoretical output integrated with their application in different } \\
\text { contexts (creation of theoretical models and their application ); } \\
\text { the central role of, and sharing of all experiences, texts and research on, the } \\
\text { ecosystem (ecological) approach, and its integration with the social dimension; } \\
\text { considerable attention to the development of local communities and regions in } \\
\text { crisis (integrating their ecological and social dimensions as a means to ensure } \\
\text { development for even the poorest communities). } \\
\text { a large scientific output (theoretical, methodological - modelling - and } \\
\text { application) concerning the sustainable management of natural resources in } \\
\text { which the sustainable management of natural resources is integrated with the } \\
\text { social aspects of local communities (for example, there are many studies and } \\
\text { experiments carried out on the management of fishery resources, and the } \\
\text { local communities connected with these, in the Nordic countries of Europe); }\end{array}$ \\
\hline
\end{tabular}

3. The Resilience Alliance is a research organisation comprised of scientists and practitioners from many disciplines who collaborate to explore the dynamics of social ecological systems. The body of knowledge developed by the RA, encompasses key concepts of resilience, adaptability and transformability and provides a foundation for sustainable development policy and practice, http://www.resalliance.org/. 


\begin{tabular}{|c|c|}
\hline $\begin{array}{l}\text { THE CITY } \\
\text { MODEL }\end{array}$ & $\begin{array}{l}\text { The Urban Resilience program }{ }^{4} \text { is a research project started in 2007. In order } \\
\text { to understand the mechanisms of resilience, the urban system is the results } \\
\text { of the inter-relations between the metabolic flows (that support the urban } \\
\text { functions, human well-being and quality of life), governance networks (the } \\
\text { ability of societies to learn to adapt and organise themselves), the social dyna- } \\
\text { mics (of people as citizens, community members, service users, consumers of } \\
\text { products and all the networks of relationships that support interrelationships } \\
\text { between communities and social populations), and the built environment (that } \\
\text { is formed from physical and spatial elements, but also, and above all, from } \\
\text { the relationships and the interconnections between them). }\end{array}$ \\
\hline $\begin{array}{l}\text { RESILIENCE AND } \\
\text { ADAPTATION }\end{array}$ & $\begin{array}{l}\text { The amount of literature and documents related to climate change adaptation } \\
\text { strategies and peak oil is enormous, including with regard to the relevance } \\
\text { of the issue. It is possible to identify two main groups: there are a number of } \\
\text { texts on the resilience of urban areas or regions (such as those by Stephen } \\
\text { Coyle or texts by authors such as Peter Newman, Peter Beatley, Heather } \\
\text { Boyer) and the initiatives of English Transition Cities (texts of Rob Hopkins } \\
\text { and Shaun Chamberlin). } \\
\text { One aspect common to these texts is that of using resilience as a key for } \\
\text { coping with the important changes taking place, and for building adaptation } \\
\text { strategies for climate change, the lack of - and fall-off in - natural resources } \\
\text { (particularly oil), and energy crises. } \\
\text { In terms of using and referring to the concepts specifically related to resilience, } \\
\text { the works focussing on cities and adaptation (e.g. Newman) do not expand } \\
\text { upon theoretical references and/or close examination of the properties or } \\
\text { principles of ecosystem resilience. } \\
\text { In the works related to Transition Cities, numerous concepts related to } \\
\text { ecosystem resilience and properties are explicitly mentioned: diversity and } \\
\text { redundancy, modularity and hierarchies/organisation and feedback processes. } \\
\text { These principles are the basis for constructing processes, strategies and actions } \\
\text { for resilient communities. }\end{array}$ \\
\hline THE CITY MODEL & $\begin{array}{l}\text { A general objective shared by these authors is the development of an action } \\
\text { plans to make in the neighbourhoods, community or region more environ- } \\
\text { mentally and economically healthy, habitable and resilient. } \\
\text { This group of authors (such as Coyle, Newman, Beatley and Boyer, for } \\
\text { example), by greatly simplifying the models devised in the texts, separate } \\
\text { out the built environment and other issues connected with networks or } \\
\text { 'supporting systems'. } \\
\text { For example, Coyle proposes a model of the city (or urban system) consisting } \\
\text { of the built environment and supporting systems. The built environment con- } \\
\text { sists of the physical structures and organisation patterns of buildings, blocks, } \\
\text { neighbourhoods, villages, towns, cities and regions. The supporting systems } \\
\text { are: Transportation, Energy, Water, Natural environment, Food production, } \\
\text { Agriculture, Solid waste, Economics. }\end{array}$ \\
\hline
\end{tabular}

\section{RESILIENCE AND RISK}

In the most innovative research and best practices aimed at the mitigation of territorial risks, the concept of resilience has assumed a central role in the construction of strategies that include within the objectives of reducing risks and hazards a plurality of goals aimed at territorial quality ${ }^{5}$.

4 CSIRO, Australia; Arizona State University, USA; Stockholm University, Sweden; Urban Resilience Research Prospectus Coordinatore Brian Walker Science Program Director and Chair; Board of Members The Resilience Alliance, February 2007.

5 See, for example, the many contributions relating to the research project on the sustainable development of the U.S. territories bordering the Gulf of Mexico, presented at the Venice Biennale, collected in the work by Eugenie L. Birch and Susan M. Wachter, Eds, 2006: Rebuilding Urban Places After Disaster: Lessons from Hurricane Katrina, University of Pennsylvania Press, Philadelphia; the best practices and researches devised by Pelling on the resilience of cities and urban systems. 
The concept of resilience in territorial risk management has now been established, certainly in scientific debate. Since that the topic of resilience has long been debated, there are also significant theoretical focal points in terms of interpretation, such as the relationship between resilience and vulnerability. As underlined Pelling the idea of resiliency suggest a proactive stance towards risks. It has been discussed within ecological theory, system analysis and disaster studies (Pelling, 2003 p.7)

The concept of resilience was initially associated with (and opposed to) the concept of vulnerability: resilience was employed as the opposite of vulnerability and resilience strategies were therefore aimed at reducing the vulnerability of systems with regard to territorial risks. Subsequently, in the context of the scientific debate, resilience was associated with a wider vision and not just related to the reduction of vulnerability. From this point of view, the approach to resilience includes dynamic aspects (increasing the resilience of a system over time including theories of adaptation, not only at the time of reaction to disasters), aspects of scale and management of complex systems (reduction of the causes and determinants of hazards and phenomena that increase the severity of disastrous events), socio-economic aspects (including both organisational and social aspects) (White, 2010).

The conceptualisation of resilience in academia has been fuzzy and contested, and some lucidity is needed to understand this relatively new theoretical construct in relation to water and spatial planning. In recent texts, the study of resilience, while related to the issue of territorial risks (clear configuration of the aim) includes more general objectives: a more resilient system with regard to territorial risks is and must be, in general, an urban-territorial system characterised by higher overall environmental and social quality.

\section{CONCEPTS OF ECOSYSTEM RESILIENCE}

The concept of resilience used by many authors is that of ecosystem resilience. Resilience is understood as the capacity and ability, after a disaster, to emerge from stalemate in a condition that is not necessarily the same as the initial pre-existing condition. The capacity of a region to be resilient largely depends on the organisation and relationships that existed before the event: the more flexible the system, the quicker will be recovery to normality from the perspective of improvement and awareness.

If a community chooses to go on living despite the risk, then growth must be directed towards creating resilient cities capable of responding to the effects of a disaster. This type of approach, namely being aware of and cooperating with nature and not against it, can simultaneously achieve the goals of conservation and exploitation of natural resources without reducing the opportunities for growth (Burby, 1998).

The integrated use of appropriate management tools and regional planning is needed to achieve a vision of resilient cities, reducing the intensity of growth in hazardous areas: by reducing the need to distort and obstruct natural processes, we will be able to reduce both the economic the social costs of vulnerable cities.

\section{RESILIENCE STRATEGIES}

In the construction of strategies for territorial resilience against risks, there are many concepts characteristic of ecosystem resilience that are used as key principles: 
- The homeostasis principle: systems are maintained by feedbacks between component parts which signal changes and enable learning. Resilience enhanced when feedbacks are transmitted effectively

- The omnivory principle: external shocks are mitigated by diversifying resource requirement and their means of delivery. Failures to source or distribute a resource can then be compensated for by alternatives.

- The high flux principle. The faster the movement of responses through a system the more resources will be available at any given to help cope with perturbation.

- The flatness principle. Overly hierarchical systems are less flexible and hence less able to cope with surprise and adjust behaviour. Top-heavy system will be less resilient

- The buffering principle: a system which has a capacity in excess of its need can draw on this capacity in times of need, and so is more resilient.

- The redundancy principle: a degree of overlapping function in a system permits to system to change by allowing vital functions to continue while formerly redundant elements take on new function. (Pelling 2003, p. 8).

Other authors (as Watson and Adams, 20I I) identifythe agenda of resilient design that can be expressed by three key principles: multiple scales of impact, collaborative design and innovation in design, technology, and policy.

These strategies/principles are also contained in official documents of many bodies (as NOOA, FEMA and ONU agencies) set up to protect populations against risks: for example, the Federal Emergency Management Agency (FEMA) has identified checklists for resilient cities/regions (related to flood plain management) or the document from the National Science and Technology Council Committee (Grand Challenges for disaster Reduction 2005, report for the White House office for science and technology) which contains actions to be implemented towards resilient systems.

The concepts common to different authors for a risk-resilient system are: diffusion and diversity (redundant and diverse city), the rapid responses properties (efficient and strong city), the redundancy circuit (feedback and smart city); the storage capacity and the scale/ hierarchy connection (independent, collaborative and adaptable city).

\section{RESILIENT CITY MODEL}

In general, the structure of the urban and regional systems proposed by the authors of this family is derived from the established methodologies and models of risk analysis and management. The local systems are broken down into subsystems and components (analysis by component: social, environmental, etc.) and into the relational components that exist between the subsystems (relational analysis: interactions between subsystems).

A set of characteristic of a "resilient city" is defined in the UNISDR report on "Making Cities Resilient" (UNISDR, Making Cities Resilient campaignReport 2012). Based on the Campaign, the report defines a resilient city as one where:

- Disasters are minimized because the population lives in homes and communities with organized services and infrastructure that adhere to sensible building codes.

M 11 REVISTA M VOL. 10 No.1. ENERO-JUNIO 2013 • FACULTAD DE ARQUITECTURA • UNIVERSIDAD SANTO TOMÁS COLOMBIA 
- An inclusive, competent and accountable local government is concerned about sustainable urbanization and that commits the necessary resources to develop capacities to manage and organize itself before, during and after a natural hazard event.

- The local authorities and the population understand their risks and develop a shared, local information base on disaster losses, hazards and risks, including who is exposed and who is vulnerable.

- People are empowered to participate, decide and plan their city together with local authorities and value local and indigenous knowledge, capacities and resources.

- Steps are taken to anticipate and mitigate the impact of disasters, incorporating monitoring and early warning technologies to protect infrastructure, community assets and individuals, including their homes and possessions, cultural heritage, environmental and economic capital, and is able to minimize physical and social losses arising from extreme weather events, earthquakes or other natural or human- induced hazards.

- There is an ability to respond, implement immediate recovery strategies and quickly restore basic services to resume social, institutional and economic activity after such an event.

- An understanding exists that most of the above is also central to building resilience to adverse environmental changes, including climate change, in addition to reducing greenhouse gas emissions.

\section{INITIAL CONCLUSIONS}

The table 2 shows a summarised comparison from this initial analysis of the literature on cities and resilience. In particular, the main disciplinary backgrounds, the scales or spatial dimensions under consideration (neighbourhoods, regions, cities, etc.), the models of urban systems and the main concepts of ecosystem resilience referred to in the texts are specified for each family.

Table 2. Families of literature: comparison synthesis. Source: Elaborated by the author.

\begin{tabular}{|c|c|c|c|c|}
\hline & $\begin{array}{l}\text { Resilience and } \\
\text { sustainability }\end{array}$ & \multicolumn{2}{|c|}{ Resilience and adaptation } & $\begin{array}{l}\text { Resilience } \\
\text { and risks }\end{array}$ \\
\hline $\begin{array}{l}\text { Disciplinary } \\
\text { backgrounds }\end{array}$ & $\begin{array}{l}\text { Natural sciences, biology, } \\
\text { ecology, economy and so- } \\
\text { cial and political sciences }\end{array}$ & \multicolumn{2}{|c|}{$\begin{array}{l}\text { Planning, architecture, natural } \\
\text { science, sociology }\end{array}$} & $\begin{array}{l}\text { Engineering, building } \\
\text { architecture, planning, } \\
\text { social science }\end{array}$ \\
\hline \multirow[b]{2}{*}{$\begin{array}{l}\text { Resilience defi- } \\
\text { nition }\end{array}$} & & $\begin{array}{l}\text { Planner } \\
\text { approach }\end{array}$ & Transition cities & \multirow{2}{*}{$\begin{array}{l}\text { R. as the capacity and } \\
\text { ability, after a disaster, } \\
\text { to emerge from sta- } \\
\text { lemate in a condition } \\
\text { that is not necessarily } \\
\text { the same as the initial } \\
\text { pre-existing condition }\end{array}$} \\
\hline & $\begin{array}{l}\text { 'R. as the capacity to lead } \\
\text { to a continued existence by } \\
\text { incorporating change' }\end{array}$ & $\begin{array}{l}\text { No definition } \\
\text { of } R \text {. }\end{array}$ & $\begin{array}{l}\text { R. as the ability } \\
\text { of complex sys- } \\
\text { tem to absorb } \\
\text { the stress using } \\
\text { adaptation stra- } \\
\text { tegies }\end{array}$ & \\
\hline $\begin{array}{l}\text { Research and } \\
\text { experiences } \\
\text { Focus (scales } \\
\text { and places) }\end{array}$ & $\begin{array}{l}\text { - Theoretical / theoretical } \\
\text { modelling } \\
\text { - Development of local } \\
\text { communities and regional } \\
\text { development } \\
\text { - Management of natural } \\
\text { resources (linked to deve- } \\
\text { lopment of local communi- } \\
\text { ty / regional development) }\end{array}$ & \multicolumn{2}{|c|}{$\begin{array}{l}\text { - Models / strategies applied to city } \\
\text { / urban and metropolitan }\end{array}$} & $\begin{array}{l}\text { - Regional development } \\
\text { - Urban contexts } \\
\text { - Projects focused on } \\
\text { specific phenomena }\end{array}$ \\
\hline
\end{tabular}




\begin{tabular}{|c|c|c|c|c|}
\hline \multirow[b]{2}{*}{$\begin{array}{l}\text { Cities model } \\
\text { (components) }\end{array}$} & \multirow[b]{2}{*}{$\begin{array}{l}\text { - Social-ecological systems } \\
\text { - Urban areas is the re- } \\
\text { sult of the interaction of } \\
\text { four system (that have } \\
\text { the same relevance): me- } \\
\text { tabolic flows, governance } \\
\text { networks, social dynamics, } \\
\text { built environment. }\end{array}$} & $\begin{array}{l}\text { Planner } \\
\text { approach }\end{array}$ & Transition cities & \multirow[b]{2}{*}{$\begin{array}{l}\text { - Cities/regional models } \\
\text { are based on traditional } \\
\text { risk analysis methods } \\
\text { - City component phy- } \\
\text { sical, social and organi- } \\
\text { zational }\end{array}$} \\
\hline & & $\begin{array}{l}\text { Cities system } \\
\text { composed by } \\
\text { the build en- } \\
\text { vi r o n m e n t } \\
\text { (center of the } \\
\text { model) suppor- } \\
\text { ted by the sup- } \\
\text { porting systems } \\
\text { (Transportation, } \\
\text { Energy, Water, } \\
\text { Natural envi- } \\
\text { ronment, Food } \\
\text { production, } \\
\text { agriculture, So- } \\
\text { lid waste, Eco- } \\
\text { nomic) }\end{array}$ & $\begin{array}{l}\text { Community } \\
\text { process of } \\
\text { changing } \\
\text { (not structured } \\
\text { models) }\end{array}$ & \\
\hline \multirow[b]{2}{*}{$\begin{array}{l}\text { Resilience con- } \\
\text { cepts used as } \\
\text { key strategies }\end{array}$} & \multirow[b]{2}{*}{$\begin{array}{l}\text { - Feeding diversity for re- } \\
\text { organization and renewal } \\
\text { - Interconnection between } \\
\text { temporal and spatial scales } \\
\text { varying } \\
\text { - Recognition of the slow } \\
\text { variables } \\
\text { - Compact strong feedback } \\
\text { - Adaptability, flexibility and } \\
\text { innovation } \\
\text { - Knowledge and com- } \\
\text { munities }\end{array}$} & $\begin{array}{l}\text { Planner } \\
\text { approach }\end{array}$ & Transition cities & \multirow[b]{2}{*}{$\begin{array}{l}\text { - Buffering } \\
\text { - Core protection } \\
\text { - Diffusion } \\
\text { - Rapid responses } \\
\text { - Redundancy circuit } \\
\text { - Storage capacity } \\
\text { - Waste nutrient } \\
\text { recovery self-help }\end{array}$} \\
\hline & & $\begin{array}{l}\text { No strong re- } \\
\text { lation between } \\
\text { resilience con- } \\
\text { cepts and the } \\
\text { strategies deve- } \\
\text { loped }\end{array}$ & $\begin{array}{l}\text { - diversity } \\
\text { - modularity } \\
\text { - local based } \\
\text { - feedback } \\
\text { - small }\end{array}$ & \\
\hline $\begin{array}{l}\text { Resilience stra- } \\
\text { tegies (innova- } \\
\text { tion for plan- } \\
\text { ning) }\end{array}$ & $\begin{array}{l}\text { - Life is full of surprises } \\
\text { - Learning to live with un- } \\
\text { certainty and change } \\
\text { - Feeding diversity for re- } \\
\text { organisation and renewal } \\
\text { - Combining different types } \\
\text { and systems of knowledge } \\
\text { and create opportunities } \\
\text { for self-organization } \\
\text { - Adaptability, flexibility } \\
\text { and innovation based on } \\
\text { feedback } \\
\text { - Memory }\end{array}$ & $\begin{array}{l}\text { No innovation } \\
\text { strictly related } \\
\text { to the resilience } \\
\text { Newman pro- } \\
\text { poses, strategies } \\
\text { related to: Re- } \\
\text { newable Ener- } \\
\text { gy City, Carbon } \\
\text { Neutral City, } \\
\text { Distributed city, } \\
\text { Photosynthe- } \\
\text { tic City, Eco- } \\
\text { Efficient City, } \\
\text { Place-B a sed } \\
\text { City, Sustainable } \\
\text { Transport City. }\end{array}$ & $\begin{array}{l}\text { - Diversity (and } \\
\text { creative redun- } \\
\text { dancy) } \\
\text { - Modularity } \\
\text { (organisational } \\
\text { networks / and } \\
\text { governance) } \\
\text { - Local-based } \\
\text { - Small } \\
\text { - Balance bet- } \\
\text { ween environ- } \\
\text { mental, social } \\
\text { and economic } \\
\text { resources, and } \\
\text { the type of de- } \\
\text { velopment and } \\
\text { their levels of } \\
\text { consumption } \\
\text { and use }\end{array}$ & $\begin{array}{l}\text { - Redundancy \& diver- } \\
\text { sity } \\
\text { - Efficiency \& Strong } \\
\text { (with the capacity to } \\
\text { withstand events/ex- } \\
\text { ternal attacks of various } \\
\text { kinds) } \\
\text { - Independency \& } \\
\text { connections (ability to } \\
\text { mutually support one } \\
\text { other) } \\
\text { - Adaptability } \\
\text { - Ability to learn from } \\
\text { experience } \\
\text { - Collaboration(multiple } \\
\text { opportunities and in- } \\
\text { centives) }\end{array}$ \\
\hline
\end{tabular}

With regard to the concepts used, we are proposing a schematic summary which attributes the key concepts used by the authors of the three families researched. The scheme highlights where the key concepts are innovative in the field of planning and urban design and where these concepts can be found in the literature or are already in use. 
The most innovative aspects and concepts shared and underlined by the three families are:

- A strong link between physical, social and organisational elements;

- Strong relevance of local community and relevance to the social aspects;

- Focus and role of ecosystem services;

- Strong innovation in terms of the process;

- Relevance of the concept of process dynamics (and therefore of flexibility with respect to the dynamism of processes).

Figure I: Schematic summary: strategic concepts, belonging and sharing (The scheme highlights (darker colour) where the key concepts are innovative in the field of urban planning/design and where these concepts can be already found or are already in use in the urban planning/design literature). Source: elaborated by the author.

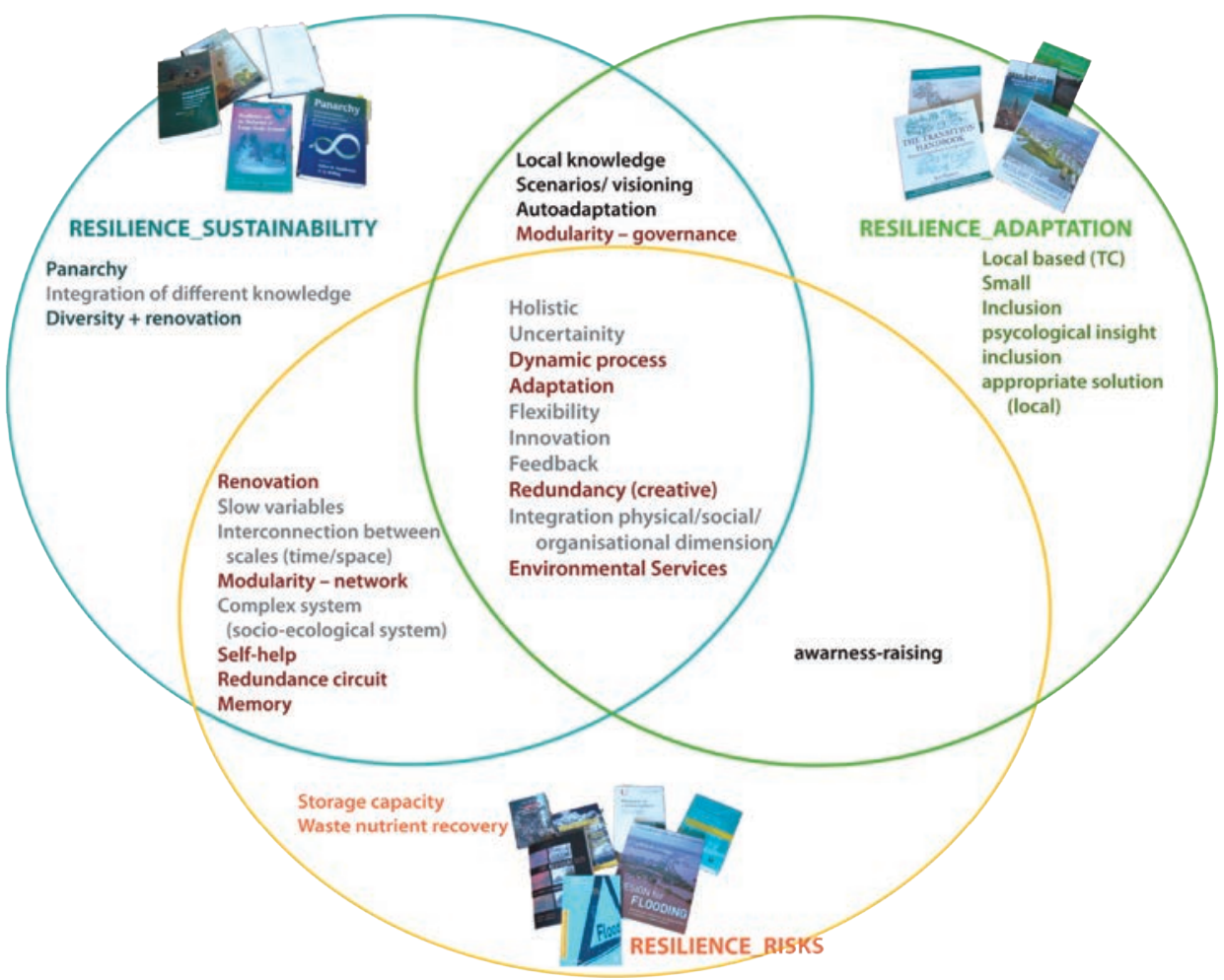

Within the context of local governance processes, the concept of resilience affords possibilities and opportunities. Certainly the concept of resilience in itself contains significant possibilities, especially in the construction of scenarios and visions shared with local communities from a positive and optimistic perspective (Hopkins, Pelling). Issues such as the protection of environmental and ecosystem performance or the prevention of local risks can be translated not only into guidelines for constraints and safeguards, but as active construction projects for resilient territorial systems and communities.

Integrating the concepts of resilience into forward thinking capabilities for plans and programmes. Many benefits are derived from the efficient functioning of ecosystems, and, therefore, considering the services and benefits that derive from ecosystems as an integral part of the system of services and functions of local systems. 
The following are the shared key strategies for resilient regions and cities.

- (Diversity and) redundancy: A resilient world promotes diversity in all its aspects and biological, landscape, social and economic forms. Diversity is a major source in terms of the options for our future. At the same time, if diversity implies the differentiation into elements and components, redundancy implies multiplicity of functions. Redundancy can also be approached through the principles of subsidiarity, understood as the interrelationship and repetition of a number of decision-making mechanisms including at the local scale. A resilient world has institutions that include some redundancy in the institutional structures and a degree of overlap between public and private in respect of access to ownership.

- Recognition of slow variables: A resilient world must have policies focused on controlling threshold-related variables. By focusing on the slow variables that give shape to social-ecological systems and on the thresholds that remain, we have a better ability to manage the resilience of the system.

- Adaptability, flexibility and innovation: A resilient world places the focus on learning, experimentation and the development of local rules, and embraces changes. One approach to resilience is to encourage new developments and innovations. In general, we aim for solutions to avoid change rather than find innovative solutions that mutate or assist the changes.

- Knowledge and communities: a resilient world fosters social networks and flexible leadership. The resilience of social-ecological systems is closely connected with people's capacity to respond jointly and effectively to changes and disturbances.

- Interconnection between spatial scales and time variables: the issue of interconnection between different spatial scales and dimensions of time is certainly complex, and widely discussed in the field of urban planning and design. Studies on complex systems, however, tell us that in a resilient system, not everything is interconnected and dependent. There are relatively independent parts. The notion of over-interconnection, especially at intermediate hierarchical levels of hierarchy implies that once one part suffers stress, this shock reverberates throughout the whole system.

- Solid strong feedback: The feedback processes allow us to perceive the thresholds before crossing them. A resilient world has strong feedback (but not too strong). In this case there are very many references to the flexibility of decision-making processes and construction plan processes (Steiner but a great many others).

\section{RESILIENCE: OPEN QUESTIONS}

The concept of resilience must be understood for the opportunities that generates in terms of responses to the critical phenomena characterising the processes of design / planning of urban and territorial systems. the resilience should not be construed as a "way of salvation" or as a "solution" to all problems (Hopkins, White and others).

If we assume as "consolidated" the definition of ecosystem resilience, the concept of resilience in relation to urban-territorial complex systems (or socio-ecosystems) is not consolidated at all (as the concept of resilience in relation to the governance/management of cities and territories). 
There is, in fact, a widespread tendency to associate and/or to overlay the concept of "resilience" to the "resilient territory/city". This overlay gives rise to some confusion. Resilience is a property of ecosystems that are characterized by numerous and complex properties and therefore can also be more or less resilient. The use "resilient city" in itself, as the only defining aspect or all-inclusive, involves the risk of reducing the opportunities and potential offered from taking on an approach to resilience and complexity that characterizes the resilience ecosystem.

Propose a "plan / project" of "city / territory resilient" could against with some principles of the resilience: the distance from stability, continuous dynamic tension towards adaptation and innovation, characteristics that make "not planed" a "status of resilient systems" in itself.

An open question is whether "resilience" could be planned: it follows from the foregoing considerations that it is not possible to design or plan a territory or a city resilient in itself, but it is certainly important and necessary to include in the processes of transformation/ development of urban-territorial systems solutions that can enhance the properties of urban and territorial systems that make them potentially more resilient.

\section{REFERENCES}

AAW (2002) Resilience and Sustainable Development: Building Adaptive Capacity in a World of Transformations (Background paper to WSSD). Scientific Background Paper on Resilience for the process of The World Summit on Sustainable Development on behalf of The Environmental Advisory Council to the Swedish Government of April 16, 2002.

Berkes, F., J. Colding, C. Folke, eds (2003). Navigating Social-Ecological Systems: Building Resilience for Complexity and Change. Cambridge University Press, Cambridge.

Burby, R. J., ed. (1998). Cooperating with Nature: Confronting Natural Hazards with Land use Planning for Sustainable Communities. Joseph Henry Press, Washington, D.C.

Campanella, T.J.; Berke, P.R. (2006). "Planning for postdisaster resiliency", in Annals of the American Academy of Political and Social Science, vol. 604.

Chamberlin, S. (2009). The Transition Timeline for a local, resilient future. Green Books Ldt., Devon UK.

Colucci, A.(20I2). Towards resilient cities. Comparing approaches/strategies, in TeMA, n $5(2)$

Colucci, A.(20I2). Le città resilienti: approcci e strategie, Polo Interregionale di Eccellenza Jean Monnet, Pavia (sito www.jeanmonnet-pv.it)

Coyle, S., ed. (20I I).Sustainable and resilient communities. A comprehensive Action Plan for Towns, Cities and Regions. Hoboken: John Wiley \& Songs Inc..

Folke, C., Colding, J. and Berkes,F. (2003). "Synthesis: building resilience and adaptive capaciy in social-ecological systems”, in Folke C., Colding J. and Berkes F., eds (2003) Navigating Social-Ecological Systems, Cambridge University Press, Cambridge 
Gunderson, L., Holling, C.S, Lance, H. (2002). "Resilience and Adaptive Cycles", in Gunderson, L., Holling, C.S., eds (2002) Panarchy: understanding transformations in human and natural systems, Island Press, Washington, D.C.

Gunderson, L., Holling, C.S., eds (2002). Panarchy: understanding transformations in human and natural systems, Island Press, Washington, D.C.

Gunderson, L., Pritchard, L. Jr., eds (2002). Resilience and the behaviour of large-scale systems. Island Press, Washington, D.C.

Janssen, M., ed. (2003). Complexity and Ecosystem Management. Edward Elgar Publishers, Northampton.

Hopkins, R. (2008). The Transition Handbook. From oil dependency to local resilience. Green Books Ldt., Devon UK.

Low, B., Ostrom E., Simon C., Wilson J. (2003). "Redundancy and Diversity: do they influence optimal management?" in Folke C., Colding J. and Berkes F. eds (2003) Navigating Social-Ecological Systems, Cambridge University Press, Cambridge.

Ostrom, E. (2005). Understanding Institutional Diversity. Princeton University Press, Princeton.

Newman, P, Beatley, P., Boyer, H. (2005). The Resilient city. How modern cities recover from disaster. Oxford University Press, Oxford.

Pelling, M. (2003). The vulnerability of cities. Natural disasters and social resilience. Earthscan, London.

Steiner, F., Sipes, J., Faga, B., and Yaro, R. (2007). Mapping for Sustainable Resilience in the Gulf Coast of the United States. PLANUM web site, Publication date: September 2007 (http://www.planum.net/topics/themesonline.html)

UN/ISDR (2004). Living With Risk: A Global Review of Disaster Reduction Initiatives. Vol. I\&II. United Nations, New York.

Vale, L. J., Campanella, T. J. (2005). The resilient city: how modern cities recover from disaster. Oxford University Press, New York.

Walker, B.H., Salt, D. (2006). Resilience Thinking: Sustaining Ecosystems and People in a Changing World. Island Press, Washington, D.C.

Watson, D., Adams, M. (20I I). Design for flooding. Architecture, landscape and urban design for resilience to climate change. John Wilwey \& Songs Inc., Hoboken.

White, A. (2010). Water and the city. Risk, Resilience and planning for a sustainable future, Routledge, Abingdon.

M 17 REVISTA M VOL. 10 No.1. ENERO-JUNIO 2013 • FACULTAD DE ARQUITECTURA • UNIVERSIDAD SANTO TOMÁS COLOMBIA 